South South African Journal of Animal Science 2018, 48 (No. 2)

\title{
Effect of Acacia angustissima leaf meal on performance, yield of carcass components and meat quality of broilers
}

\author{
S. Ncube ${ }^{\#}$, T.E. Halimani, E.V.I. Chikosi \& P.T. Saidi \\ University of Zimbabwe, Faculty of Agriculture, Department of Animal Science Box MP167, Mt Pleasant, Harare, \\ Zimbabwe
}

(Received 25 August 2017; Accepted 1 December 2017; First published online 21 December 2017)

Copyright resides with the authors in terms of the Creative Commons Attribution 4.0 South African License.
See: http://creativecommons.org/licenses/by/4.0/za

\begin{abstract}
The study determined the appropriate levels of including Acacia angustissima leaf meal in broiler diets for optimum performance, carcass part yield, and meat quality characteristics. One hundred and fifty broiler chicks were allocated to $0 \%, 5 \%$, and $10 \%$ A. angustissima leaf meal-based diets in a completely randomized design, with five replicates per treatment. Weekly feed intake and live weights were measured. Weekly weight gains and feed conversion ratios were calculated. At six weeks, two birds per replicate were slaughtered and dressed. Carcass and portion yields were determined. Breast proximate components, CIELAB colour variations, cooking loss and shear force were estimated. Consumer preferences for colour, aroma, taste, flavour and tenderness were determined. Voluntary feed intake (VFI), weekly weight gain, weekly live weights and feed conversion ratios (FCR) were the same across treatments at two weeks. At weeks 4 and 6 , the control and $5 \%$ groups outperformed the 10\% group. Increasing dietary leaf meal had no effect on dressing out percentage, but decreased carcass weight from $1456 \mathrm{~g}$ to $1060 \mathrm{~g}$, breast yield from $36.83 \%$ to $32.69 \%$, breast meat to bone ratio from $4.77 \%$ to $2.94 \%$, and proportion of drumstick skin from $11.57 \%$ to $7.92 \%$. It also resulted in increased yield of thighs from $14.63 \%$ to $15.97 \%$, proportion of thigh skin from $11.50 \%$ to $14.31 \%$ and breast skin proportion from $5.37 \%$ to $7.95 \%$. The leaf meal had no effect on the proximate components of breast meat. The $L^{*}$ values decreased from 53.66 to 49.23 ; the $b^{*}$ values increased from 12.93 to 19.97 ; shear force increased from $14.14 \mathrm{~N}$ to $14.54 \mathrm{~N}$; and cooking loss increased from $5.95 \%$ to $7.64 \%$ with increasing leaf meal levels. It was concluded that up to $5 \%$ A. angustissima leaf meal inclusion has no negative effect on performance, yield of carcass parts and meat quality characteristics of broilers.
\end{abstract}

Keywords: Breast, colour, cooking loss, shear force, taste

\#Corresponding author: sharaincube7@gmail.com

\section{Introduction}

High feed costs (Bonsu et al., 2012) and competition for feed/food resources between human beings and poultry (Muktar et al., 2015) hinder the growth of the poultry industry in most developing countries, hence the need to explore the use of non-conventional feed resources, especially those that do not attract competition between humans and monogastric animals. Leaf meal from Acacia angustissima tree, a multipurpose shrub legume, is one such resource. It is a thornless shrub legume tree of 2-7 $\mathrm{m}$ in height, with leaf capacity to produce leaf biomass of up to $12.4 \mathrm{t} \mathrm{DM} \mathrm{Ha}^{-1}$ (Preece \& Brook, 1999). It has shown superior fodder production characteristics (Dzowela et al., 1997; Hove et al., 1999; Reed et al., 2001) and ability to resist psyllid attack (Odenyo et al., 2003) compared with other shrubs under southern African conditions, making it a fodder tree of choice. Its potential to support broiler growth (Ncube et al., 2012abc) and its effect on the physiological functions of broilers (Ncube et al., 2017a, b) have been established. To date, optimum inclusion levels of the leaf meal in support of growth without negative effects on the digestive and metabolic processes have been established at 5\% (Ncube et al., 2017a, b). However, little is known about the effects of the same diets as used by Ncube et al. $(2017 \mathrm{a}, \mathrm{b})$ on the yield of carcass parts and meat quality parameters. Thus, there is a need to determine levels at which the leaf meal would support acceptable yield of carcass parts, while simultaneously producing meat of acceptable chemical, physical, and organoleptic characteristics in broilers without compromising performance. 
Consideration of carcass part yield is important because marketing of broilers has shifted from whole chicken to portions (Rostagno et al., 2007). It is therefore important to give attention to the effect of the leaf meal on the yield of carcass parts. This is especially important for the breast, a portion of economic importance (Scheuermann et al., 2003; Petracci \& Cavani, 2012; Shim et al., 2012). Since breast muscle provides the greatest portion of edible meat in broilers (Al-Owaimer et al., 2014), any new feeding intervention should consider the impact on breast yield and quality characteristics. Previous studies have focused on determining possible deleterious effects, and growth and fat reduction in broilers fed $A$. angustissima leaf meal-based diets. Consequently, 5\% (Ncube et al., 2012a) and 10\% (Ncube et al., 2012c) inclusion levels were recommended for optimum growth and reduction of fat, respectively, without affecting carcass weight. These past studies, as well as the most recent studies by Ncube et al. (2017ab), are silent on the possible effect of the leaf meal on yield of carcass parts. Information on portion yield could also help broiler producers decide on suitable markets (Faria et al., 2010) to optimize profits. While some markets may prefer portioned carcasses (Faria et al., 2010) others would rather have whole chicken carcasses (Karaoğlu et al., 2014).

Increased consumer awareness of meat quality is also a key driver in efforts to determine the effect of the leaf meal on meat quality characteristics. This would ensure satisfaction of consumer expectations (Grunert et al., 2004). Such expectations are addressed by the relationship between quality expectation and quality experience. The smaller the gap between expected and experienced quality, the higher the levels of satisfaction. Therefore, recommendations on the use of $A$. angustissima leaf meal in broiler diets should consider its effect on major meat quality parameters, such as the chemical composition, and physical and organoleptic attributes. This would help reduce the chances of product rejection in the market. Current recommendations on the use of the leaf meal in broiler diets are silent on its effect on meat quality parameters; hence, the need to determine the appropriate level of including in broiler diets for optimum growth and meat quality characteristics. The objective of this study was therefore to determine the appropriate levels of including Acacia angustissima leaf meal in broilers diets for optimum performance, carcass part yield and meat quality characteristics.

\section{Materials and Methods}

A. angustissima leaves were harvested at the mid maturity stage of growth and air dried in a wellventilated room (Ncube et al., 2015). The dried samples were ground through a 1-mm sieve, sealed tightly in bags, and stored in a cool dry place for chemical analysis. Dry matter, crude protein, crude fibre, and ash contents were determined using AOAC (1990) methods. The content of condensed tannins was determined using the Butanol-HCL method (Porter et al., 1986). Soluble and insoluble fibres were determined through a procedure by Parsaie et al. (2006) (Table 1). Using the proximate composition of the leaf meal, three isonitrogenous and iso-energetic diets were formulated for a three-phase feeding programme at $0 \%, 5 \%$, and $10 \%$ leaf meal inclusion (Table 2). One hundred and fifty day-old unsexed Cobb 500 broiler chicks were randomly allocated to 15 groups with 10 birds per group. The groups were randomly allocated to the three diets. The starter, grower, and finisher diets were fed from Week 1 to 2, Week 3 to 4 , and Week 5 to 6 , respectively. Environmental temperature was kept at $35^{\circ} \mathrm{C}$ in the first week of life and gradually reduced to $22{ }^{\circ} \mathrm{C}$ by the fourth week. Feed and water were provided ad libitum throughout the trial. Broilers were kept under a 24-hour light schedule.

Table 1 Chemical composition of Acacia angustissima leaf meal

\begin{tabular}{lc}
\hline Chemical component & Percentage (\%) \\
\hline Dry matter & 90.00 \\
Ash & 4.77 \\
Crude protein & 23.40 \\
Crude fibre & 13.00 \\
Calcium & 0.94 \\
Phosphorus & 0.17 \\
Condensed tannins & 1.06 \\
Insoluble dietary fibre & 9.24 \\
Soluble dietary fibre & 4.96 \\
\hline
\end{tabular}


Table 2 Ingredient and chemical composition of starter, grower and finisher diets with increasing levels of Acacia angustissima leaf meal

\begin{tabular}{|c|c|c|c|c|c|c|c|c|c|}
\hline \multirow{2}{*}{ Ingredient (kg) } & \multicolumn{3}{|c|}{ Starter diets } & \multicolumn{3}{|c|}{ Grower diets } & \multicolumn{3}{|c|}{ Finisher diets } \\
\hline & Control & Diet 1 & Diet 2 & Control & Diet 1 & Diet 2 & Control & Diet 1 & Diet 2 \\
\hline Soya meal & 30.00 & 25.00 & 20.00 & 18.7 & 13.70 & 8.70 & 18.60 & 13.60 & 8.60 \\
\hline Meat and bone meal & 5.00 & 5.00 & 5.00 & 5.00 & 5.00 & 5.00 & 5.00 & 5.00 & 5.00 \\
\hline Sorghum meal & 10.00 & 0.00 & 10.00 & 0.00 & 9.90 & 10.00 & 0.00 & 0.00 & 0.00 \\
\hline Acacia leaf meal & 0.00 & 5.00 & 10.00 & 0.00 & 5.00 & 10.00 & 0.00 & 5.00 & 10.00 \\
\hline Blood meal & 0.00 & 0.00 & 0.00 & 0.00 & 2.00 & 3.00 & 1.20 & 1.80 & 3.00 \\
\hline Sunflower cake & 2.50 & 1.30 & 0.00 & 1.70 & 1.50 & 2.1 .0 & 0.00 & 0.00 & 0.00 \\
\hline L. Threonine & 0.06 & 0.06 & 0.03 & 0.05 & 0.00 & 0.45 & 0.00 & 0.00 & 0.00 \\
\hline Soya oil & 0.00 & 0.00 & 0.00 & 0.00 & 1.60 & 3.00 & 0.00 & 1.30 & 2.40 \\
\hline Wheat bran & 0.00 & 0.00 & 2.10 & 0.00 & 0.00 & 0.00 & 0.00 & 0.00 & 0.00 \\
\hline Soya oil & 0.00 & 0.00 & 1.50 & 0.00 & 0.00 & 0.00 & 0.00 & 0.00 & 0.00 \\
\hline Maize meal & 48.60 & 56.90 & 44.00 & 68.1 & 55.00 & 51.40 & 73.00 & 70.40 & 67.50 \\
\hline Fish meal & 1.20 & 4.90 & 5.00 & 4.6 & 4.60 & 5.00 & 0.10 & 1.00 & 2.00 \\
\hline DL Methionine & 0.30 & 0.29 & 0.79 & 0.19 & 0.16 & 0.11 & 0.15 & 0.15 & 0.07 \\
\hline Lysine HCL & 0.26 & 0.22 & 0.28 & 0.21 & 0.14 & 0.12 & 0.00 & 0.00 & 0.00 \\
\hline Monocalcium phosphate & 0.50 & 0.30 & 0.30 & 0.2 & 0.30 & 0.30 & 0.16 & 0.15 & 0.07 \\
\hline Limestone & 0.88 & 0.43 & 0.40 & 0.65 & 0.50 & 0.27 & 0.74 & 0.55 & 0.36 \\
\hline Salt & 0.40 & 0.30 & 0.30 & 0.3 & 0.30 & 0.25 & 0.35 & 0.35 & 0.30 \\
\hline Broiler premix ${ }^{123}$ & 0.30 & 0.30 & 0.30 & 0.3 & 0.30 & 0.30 & 0.30 & 0.30 & 0.30 \\
\hline Total & 100.00 & 100.00 & 100.00 & 100.00 & 100.00 & 100.00 & 100.00 & 100.00 & 100.00 \\
\hline \multicolumn{10}{|l|}{ Chemical composition } \\
\hline Crude protein $(\mathrm{g} / \mathrm{kg})$ & 226.00 & 226.13 & 225.28 & 199.90 & 199.74 & 200.12 & 175.00 & 174.94 & 174.93 \\
\hline $\mathrm{ME}(\mathrm{MJ} / \mathrm{kg})$ & 12.50 & 12.46 & 12.39 & 13.09 & 13.07 & 13.08 & 13.20 & 13.21 & 13.18 \\
\hline $\mathrm{EE}(\mathrm{g} / \mathrm{kg})$ & 36.80 & 39.04 & 51.94 & 41.64 & 55.17 & 67.71 & 39.19 & 51.27 & 61.45 \\
\hline $\mathrm{CF}(\mathrm{g} / \mathrm{kg})$ & 41.50 & 40.15 & 49.98 & 34.38 & 39.88 & 46.84 & 31.90 & 37.88 & 43.86 \\
\hline $\mathrm{Ca}(\mathrm{g} / \mathrm{kg})$ & 9.98 & 9.52 & 9.88 & 9.22 & 5.59 & 5.60 & 4.93 & 8.63 & 8.74 \\
\hline$P(g / k g)$ & 7.08 & 7.10 & 7.04 & 6.53 & 6.61 & 6.58 & 6.00 & 6.02 & 6.08 \\
\hline Condensed tannins (\%) & 0.004 & 0.059 & 0.076 & 0.0036 & 0.056 & 0.083 & 0.0043 & 0.055 & 0.077 \\
\hline
\end{tabular}

${ }^{1}$ Composition: 9.9u.i vitamin $\mathrm{A}, 1.95 \mathrm{u}$.i vitamin $\mathrm{D}_{3}$, 30u.i vitamin $\mathrm{E}, 2.9 \mathrm{~g}$ vitamin $\mathrm{K} 3,2 \mathrm{~g}$ vitamin $\mathrm{B} 1,7.5 \mathrm{~g}$ vitamin $\mathrm{B} 2,30 \mathrm{~g}$ vitamin PP niacin, $12.1 \mathrm{~g}$ vitamin B5, $3 \mathrm{~g}$ vitamin B6, $1 \mathrm{~g}$ vitamin b9 folic acid, 150mg vitamin B7/biotin, 20mg vitamin B12, $300 \mathrm{~g}$ choline, $60 \mathrm{~g}$ Iron, $10 \mathrm{~g}$ copper, $100 \mathrm{~g}$ manganese, $100 \mathrm{~g}$ Zinc, $1 \mathrm{~g}$, iodine, $0.5 \mathrm{~g}$ cobalt, $300 \mathrm{mg}$ selenium

${ }^{2}$ Composition: 8u.i vitamin A, 2u.i vitamin D, 25u.i vitamin E, $2 \mathrm{~g}$ vitamin $\mathrm{K} 3,1.75 \mathrm{~g}$ vitamin B1, $6 \mathrm{~g}$ vitamin $\mathrm{B} 2,25 \mathrm{~g}$ vitamin PP niacin, $10 \mathrm{~g}$ vitamin B5, $2 \mathrm{~g}$ vitamin B6, $1 \mathrm{~g}$ vitamin B9 folic acid, $100 \mathrm{mg}$ vitamin B7/biotin, $15 \mathrm{mg}$ vitamin B12, $250 \mathrm{~g}$ choline, $50 \mathrm{~g}$ iron, $8 \mathrm{~g}$ copper, $80 \mathrm{~g}$ manganese, $80 \mathrm{~g}$ zinc, $1 \mathrm{~g}$, iodine , $0.5 \mathrm{~g}$ cobalt, $250 \mathrm{mg}$ selenium

${ }^{3}$ Composition: 6u.i vitamin $A, 1.5 \mathrm{u} . \mathrm{i}$ vitamin $D_{3}$, 20u.i vitamin $\mathrm{E}, 1.5 \mathrm{~g}$ vitamin $\mathrm{K} 3,1.5 \mathrm{~g}$ vitamin $\mathrm{B} 1,5 \mathrm{~g}$ vitamin $\mathrm{B} 2,25 \mathrm{~g}$ vitamin PP niacin, $8 \mathrm{~g}$ vitamin B5, $1.5 \mathrm{~g}$ vitamin B6, $0.6 \mathrm{~g}$ vitamin $\mathrm{B} 9$ folic acid, $80 \mathrm{mg}$ vitamin B7/biotin, 15mg vitamin B12, $200 \mathrm{~g}$ choline, $40 \mathrm{~g}$ iron, $6 \mathrm{~g}$ copper, $80 \mathrm{~g}$ manganese, $60 \mathrm{~g}$ zinc, $1 \mathrm{~g}$, lodine, $0.25 \mathrm{~g}$ cobalt, $200 \mathrm{mg}$ selenium ME: Mechanical energy; CF: Crude fibre; EE: Ether extract

VFI and live weights of broilers were taken weekly. Weekly weight gain and FCR were calculated. At week 6, two broilers per replicate were randomly selected, weighed, slaughtered, and dressed. Cold dressed weight was measured and expressed as a percentage of live weight. Each carcass was cut into breasts, drumsticks, thighs, wings, back and chest. The yields of the various cuts were expressed as a proportion of cold dressed weight. The breast, thighs, and drumsticks were further separated into skin, flesh and bone. 
Each of the components was weighed and expressed as a percentage of the portion weight. Meat to bone ratios for the drumstick, thigh, and breast were calculated (Marcu et al., 2013).

The colour values of the CIELAB colour system - $L^{*}$ (lightness), $a^{*}$ (redness), and $b^{*}$ (yellowness) were determined. Pictures of the breast muscles were taken 15 hours after slaughter, before freezing, using a digital Canon Powershot SX400IS, with 16 megapixels, under daylight conditions without a camera flash. Adobe Photoshop Extended CS6 was used to determine the colour of the breast meat (Yam \& Papadakis, 2004). The chemical composition of breast meat was determined using the AOAC (1990) procedure for dry matter, crude protein, crude fat and ash contents. Remaining breast samples were frozen for assessment of physical and organoleptic attributes. The frozen breast meat samples were thawed at $3{ }^{\circ} \mathrm{C}$ for 24 hours. A sample of $150 \mathrm{~g}$ were taken from each breast muscle, placed in a tight PVC bag, cooked in a water bath heated to $100{ }^{\circ} \mathrm{C}$ for 30 minutes, and cooled at room temperature. The water released after cooking and cooling was separated manually, and the weight of the cooked meat was taken to calculate the cooking loss using the following formula:

$$
\text { Cooking loss }=\left[\frac{\text { weight of sample before cooking -weight of sample after cooking }}{\text { Weight of sample before cooking }}\right] \times 100 \%
$$

The cooked samples were used to determine shear force. Using a hand-held coring device, three cores of $1.2 \mathrm{~cm}$ in diameter were removed from each breast parallel to the longitudinal orientation of the muscle fibre so that the shearing action was perpendicular to the longitudinal orientation of the muscle fibres. Shearing of the cores was done by a Chatillan Warner-Bratzler shear machine of 50 LB capacity from G-R Manufacturing, Manhattan, Kansas, USA (serial number 13419), calibrated to a cutting speed of $2 \mathrm{~mm}$ per second. Core shearing was done at the centre, avoiding possible hardening at the end of the cores. For each breast, shear force was reported as the average of three replicates.

One hundred and thirty consumer panellists were randomly selected from the University of Zimbabwe community. Samples were thawed, washed individually in clean water, cut into cubes of $1 \mathrm{~cm} \times 1 \mathrm{~cm} \times 0.5$ $\mathrm{cm}$, and packed in transparent double-layer polythene bags per treatment and tagged for identification. The bagged meat was boiled in water for 30 minutes, wrapped in aluminium foil, labelled with three-digit random numbers and placed in warmed chafing dishes. The samples were presented randomly to panellists in different orders (AMSA, 2012). Each panellist ranked the samples on colour, aroma, flavour, juiciness, taste, tenderness and overall liking on a five-point hedonic scale, 1 referring to 'extremely like' and 5 to 'extremely dislike' For abnormal chicken flavour intensity, the scoring varied from extremely strong to extremely weak. The panellists were trained to infer and record the score for each variable. The waiting period between sample tastings was 10 minutes. Distilled water was served to panellists to rinse their mouths between subsample assessments (AMSA, 2012).

All data were analysed using Statistical Analysis System version 9.3 (SAS, 2010). The general linear model (GLM) procedure of SAS was used to determine the effect of diet on VFI, live weight, FCR, dressing percentage, chemical and physical characteristics of broiler meat. Organoleptic scores were ranked (PROC RANK) before analysis with the GLM procedure. Post hoc tests on the means or mean ranks were conducted with the Tukey-adjusted LSD method. Principal component analysis used PROC PRINCOMP to identify the organoleptic parameters that contributed to the highest variation in observed scores of each of the organoleptic parameters. Initial component patterns were obtained with PROC FACTOR and rotated with ROTATE = VARIMAX in SAS. Kaiser's Eigenvalue-greater-than-one rule was used to select the most important principal components (Kaiser, 1960).

\section{Results and Discussion}

An interaction was noted between age of birds and treatment on VFI, live weight gain, live weight and FCR $(P<0.0001)$ (Tables $3,4,5$ and 6$)$. VFI was the same across treatments $(P>0.05)$ for the starter feeding period (Weeks 1 and 2) (Table 3). Significant variations with increasing levels of $A$. angustissima in VFI were noted during the growing phase (Weeks 3 and 4) and finishing phase (Week 5 and 6) of feeding. In the grower feeding phase, feed intake from birds on the control diet was higher than the birds fed $10 \%$ leaf meal $(P<0.05)$, but the same as the birds fed 5\% $(P>0.05)$. During the finishing period, birds from the $5 \%$ diet consumed more than those on the control and $10 \%$ diets $(P<0.05)$. VFI of birds on the control and $5 \%$ diets was superior to that of the birds on the $10 \%$ diet by the end of the finishing period $(P<0.05)$. Weekly weight gains (Table 4), live weights (Table 5), and FCR (Table 6) were the same across treatments during the starter phase $(P>0.05)$. For both the grower and finisher phases, birds on the control and $5 \%$ leaf meal diet gained more and were heavier, with better FCRs than those on the $10 \%$ diet $(P<0.05)$. 
Table 3 Voluntary feed intake (g) of broilers on increasing levels of Acacia angustissima leaf meal diets at different ages of growth

\begin{tabular}{|c|c|c|c|c|}
\hline \multirow{2}{*}{ Week } & \multicolumn{3}{|c|}{ Treatment } & \multirow{2}{*}{ Standard Erro } \\
\hline & Control & $5 \%$ A. A & $10 \%$ A. A & \\
\hline 1 & $112.40^{\mathrm{a}}$ & $113.60^{a}$ & $116.60^{a}$ & 18.2 \\
\hline 2 & $274.20^{a}$ & $281.60^{a}$ & $297.00^{a}$ & 18.2 \\
\hline 3 & $492.44^{a}$ & $475.76^{\mathrm{ab}}$ & $428.32^{b}$ & 18.2 \\
\hline 4 & $648.00^{\mathrm{a}}$ & $666.40^{\mathrm{a}}$ & $625.00^{\mathrm{a}}$ & 18.2 \\
\hline 5 & $767.99^{\mathrm{a}}$ & $841.29^{b}$ & $735.72^{\mathrm{a}}$ & 18.2 \\
\hline 6 & $773.88^{a}$ & $765.61^{a}$ & $718.17^{b}$ & 18.2 \\
\hline
\end{tabular}

${ }^{\mathrm{ab}}$ Within a row, means without a common superscript differ $(P<0.05)$

A. A: Acacia angustissima

Table 4 Average live weight gain (g) of broilers on increasing levels of Acacia angustissima leaf meal diets at different stages of growth

\begin{tabular}{lcccc}
\hline \multirow{2}{*}{ Week } & \multicolumn{3}{c}{ Treatment } & \multirow{2}{*}{ Standard Error } \\
\cline { 2 - 4 } & Control & $\mathbf{5 \%} \mathbf{A . ~ A}$ & $\mathbf{1 0 \%} \mathbf{A . \mathbf { A }}$ & 17.24 \\
\hline & $95.74^{\mathrm{a}}$ & $92.84^{\mathrm{a}}$ & $87.22^{\mathrm{a}}$ & 17.24 \\
3 & $173.88^{\mathrm{a}}$ & $191.36^{\mathrm{a}}$ & $196.46^{\mathrm{a}}$ & 17.24 \\
4 & $338.50^{\mathrm{a}}$ & $305.84^{\mathrm{a}}$ & $170.46^{\mathrm{b}}$ & 17.24 \\
5 & $403.40^{\mathrm{a}}$ & $430.00^{\mathrm{a}}$ & $292.20^{\mathrm{b}}$ & 17.24 \\
6 & $362.40^{\mathrm{a}}$ & $416.40^{\mathrm{a}}$ & $320.00^{\mathrm{a}}$ & 17.24 \\
\hline
\end{tabular}

${ }^{\mathrm{ab}}$ Within a row, means without a common superscript differ $(P<0.05)$

A. A: Acacia angustissima

Table 5 Average live weights $(\mathrm{g})$ of broilers on increasing levels of Acacia angustissima leaf meal diets at different stages of growth

\begin{tabular}{lcccc}
\hline \multirow{2}{*}{ Week } & \multicolumn{3}{c}{ Treatment } & \multirow{2}{*}{ Standard Error } \\
\cline { 2 - 4 } & Control & $\mathbf{5 \% ~ A . ~ A ~}$ & $\mathbf{1 0 \%} \mathbf{A . ~ A}$ & 34.36 \\
1 & $138.02^{\mathrm{a}}$ & $112.82^{\mathrm{a}}$ & $129.34^{\mathrm{a}}$ & 34.36 \\
3 & $311.90^{\mathrm{a}}$ & $325.82^{\mathrm{a}}$ & $326.80^{\mathrm{a}}$ & 34.36 \\
4 & $650.50^{\mathrm{a}}$ & $631.70^{\mathrm{a}}$ & $497.26^{\mathrm{b}}$ & 34.36 \\
5 & $1053.60^{\mathrm{a}}$ & $1061.60^{\mathrm{a}}$ & $789.20^{\mathrm{b}}$ & 34.36 \\
6 & $1416.00^{\mathrm{a}}$ & $1418.00^{\mathrm{a}}$ & $1109.20^{\mathrm{b}}$ & 34.36
\end{tabular}

\footnotetext{
${ }^{\mathrm{ab}}$ Within a row, means without a common superscript differ $(P<0.05)$
}

A. A: Acacia angustissima 
Table 6 Feed conversion ratios of broilers on increasing levels of Acacia angustissima leaf meal diets at different stages of growth

\begin{tabular}{lcccc}
\hline \multirow{2}{*}{ Week } & \multicolumn{3}{c}{ Treatment } & \multirow{2}{*}{ Standard Error } \\
\cline { 2 - 4 } & Control & $\mathbf{5 \%}$ leaf meal & $\mathbf{1 0 \% \text { leaf meal }}$ \\
\hline 1 & $1.18^{\mathrm{a}}$ & $1.22^{\mathrm{a}}$ & $1.33^{\mathrm{a}}$ & 0.102 \\
3 & $1.73^{\mathrm{a}}$ & $1.47^{\mathrm{a}}$ & $1.51^{\mathrm{a}}$ & 0.102 \\
4 & $1.48^{\mathrm{a}}$ & $1.56^{\mathrm{a}}$ & $2.15^{\mathrm{b}}$ & 0.102 \\
5 & $1.61^{\mathrm{a}}$ & $1.56^{\mathrm{a}}$ & $2.51^{\mathrm{b}}$ & 0.102 \\
6 & $2.15^{\mathrm{a}}$ & $2.09^{\mathrm{a}}$ & $2.30^{\mathrm{a}}$ & 0.102 \\
& $2.18^{\mathrm{a}}$ & $2.31^{\mathrm{a}}$ & $2.52^{\mathrm{b}}$ & 0.102 \\
\hline
\end{tabular}

${ }^{\mathrm{ab}}$ Within a row, means without a common superscript differ $(P<0.05)$

During the starter phase of growth, intake was not affected by treatment, implying the possibility of using $A$. angustissima leaf meal in broiler starter diets without negative effects on performance. While it is generally believed that broilers eat to satisfy energy requirements (Zijlstra et al., 1999; Leeson, 2002; Mbajiorgu et al., 2011), Taylor-Pickard \& Spring (2008) indicated that broilers are able to do this only after two weeks old when the digestive systems have reached maturity. Mbarjiorgu et al. (2011) also reported that the effect of metabolizable energy (ME) on intake seem to have a greater effect during the growing and finishing phases of growth. Since maintenance requirements are a function of bodyweight and ME requirements for weight gain are a function of age of birds (Sakamura, 2004), it is also possible that the ME requirements and protein needs for weight gain were easily met at the given intake levels. As a result, weekly weights of the birds were the same across the three treatments by the end of the first two weeks, implying adequacy of nutrients across the three diets. Since VFI determines nutrient intake (Zijlstra et al., 1999; Mbarjiorgu et al., 2011), the results imply a possibility of using leaf meal in broiler starter diets without affecting nutrient intake and broiler growth performance.

Higher VFI during the growing and finisher phases of feeding also translated to superior live weight and weight gain for birds on the control and $5 \%$ leaf meal-based diets. According to Scott (2005), growth rate is influenced by feed intake. High positive correlations between VFI and growth rate were reported by Ferket \& Gernat (2006). The higher weights during the growing and finishing phases for birds on the $5 \%$ and control diets could also be attributed to better FCRs associated with the two diets, compared with the $10 \%$ leaf meal-based diet, possibly because of its higher crude fibre content. It is also possible that during the growing and finishing phases of growth, inclusion of leaf meal had a nutrient diluting effect, given its fibrous nature. Since birds eat to satisfy their energy needs (Mbarjiorgu et al., 2011; Rosa et al., 2007), feed intake increased to cater for these needs. At $5 \%$ inclusion the dilution effect might not have been severe enough to cause insufficiency of nutrients compared with the $10 \%$ diet. Under such nutritional conditions, birds overeat in compensation (Richards \& Proszkowiec-Weglarz, 2007; Uchegbu et al., 2009; McDonald et al., 2010; Sahraei, 2012). In addition, high levels of fibre might have increased the bulkiness at $10 \%$ inclusion, in which case gastrointestinal capacity becomes the limiting VFI factor. The increase in the concentration of condensed tannins may have contributed to the lowered intake at 10\% inclusion. Tanniferous ingredients confer a bitter taste to the feed (Frutos et al., 2004; Onyimonyi et al., 2009; Medugu et al., 2010; Onunkwo \& George, 2015), but given the inability of broilers to detect taste, and the fibrous nature of the leaf meal, it is likely that feed intake was highly controlled by the gastrointestinal capacity of the broilers (McDonald et al., 2010).

Table 7 shows the carcass weight, dressing percentage and proportional yield of the various parts of broilers fed different levels of the leaf meal. Treatment had no effect on dressing percentage. However, $10 \%$ inclusion significantly reduced carcass weight $(P<0.05)$. Inclusion of $A$. angustissima leaf meal had no influence $(P>0.05)$ on the proportional yield of abdominal fat, wings, back, chest portions, entire drumstick and meat to bone ratio in thighs and drumsticks $(P>0.05)$. Breast meat to bone ratio decreased with increasing levels of $A$. angustissima leaf meal. Birds on $10 \%$ diet had significantly lower breast flesh with higher proportional yield of breast bone and thigh bone than birds on the control and $5 \%$ diets. Broilers fed diets with leaf meal had higher thigh and breast skin yield and lower drumstick skin than the control $(P$ $<0.05)$. 
The decrease in the weight of drumstick skin is a favourable response to reducing the economic losses associated with skin removal during processing and cooking. It also supports the expectations of today's health conscious society whereby skin from chicken meat is removed because of wax diesters and unusual triglycerides, which are bad for human health (Tinôco et al., 2003). Thus a decline in proportion of drumstick skin on addition of $A$. angustissima leaf meal increases the nutritional and economic value of the portion. The significant increase in the breast and thigh skin proportion could lead to a loss of economic value of those parts with increasing levels of leaf meal.

Table 7 Carcass yield of broilers fed increasing levels of Acacia angustissima

\begin{tabular}{lccccc}
\hline Variable (\%) & Control & $\mathbf{5 \%} \mathbf{A . ~ A}$ & $\mathbf{1 0 \%} \mathbf{A . ~ A}$ & $\mathbf{S E}$ & $\boldsymbol{P}$ Value \\
\hline Carcass weight & $1476.45^{\mathrm{a}}$ & $1390.35^{\mathrm{a}}$ & $1060.10^{\mathrm{b}}$ & 47.659 & $<0.0001$ \\
Dressing \% & 70.00 & 68.00 & 65.00 & 1.700 & 0.1397 \\
Abdominal fat & 2.08 & 1.84 & 1.81 & 0.158 & 0.4480 \\
Entire drumstick & 12.99 & 13.21 & 13.93 & 0.301 & 0.0930 \\
Drumstick skin & $11.57^{\mathrm{a}}$ & $8.84^{\mathrm{b}}$ & $7.92^{\mathrm{b}}$ & 0.840 & 0.0110 \\
Drumstick flesh & 61.31 & 63.50 & 64.72 & 0.993 & 0.0650 \\
Drumstick bones & 26.50 & 26.70 & 26.98 & 0.691 & 0.8880 \\
Drumstick meat : bone & 2.35 & 2.38 & 2.41 & 0.084 & 0.8880 \\
Entire Thigh & $14.63^{\mathrm{a}}$ & $15.07^{\mathrm{ab}}$ & $15.97^{\mathrm{b}}$ & 0.262 & 0.0040 \\
Thigh skin & $11.50^{\mathrm{a}}$ & $14.31^{\mathrm{b}}$ & $13.71^{\mathrm{b}}$ & 0.633 & 0.0100 \\
Thigh flesh & 69.63 & 71.40 & 68.72 & 1.211 & 0.2930 \\
Thigh bones & $16.49^{\mathrm{a}}$ & $18.78^{\mathrm{a}}$ & $23.47^{\mathrm{b}}$ & 0.867 & $<0.0001$ \\
Thigh meat: bone & 3.98 & 4.29 & 3.89 & 0.170 & 0.2320 \\
Entire Breast & $36.83^{\mathrm{a}}$ & $35.44^{\mathrm{a}}$ & $32.69^{\mathrm{b}}$ & 0.734 & 0.0020 \\
Breast skin & $5.37^{\mathrm{a}}$ & $7.03^{\mathrm{b}}$ & $7.95^{\mathrm{b}}$ & 0.345 & $<0.0001$ \\
Breast flesh & $77.04^{\mathrm{a}}$ & $74.09^{\mathrm{a}}$ & $68.20^{\mathrm{b}}$ & 0.968 & $<0.0001$ \\
Breast bone & $16.49^{\mathrm{a}}$ & $18.78^{\mathrm{a}}$ & $23.47^{\mathrm{b}}$ & 0.871 & $<0.0001$ \\
Breast meat : bone & $4.77^{\mathrm{a}}$ & $4.11^{\mathrm{a}}$ & $2.94^{\mathrm{b}}$ & 0.254 & $<0.0001$ \\
Wings & 11.75 & 11.20 & 11.68 & 0.243 & 0.2160 \\
Back & 11.64 & 11.60 & 12.19 & 0.491 & 0.6330 \\
Chest & 5.69 & 5.17 & 5.18 & 0.215 & 0.1710 \\
\hline
\end{tabular}

${ }^{a b c}$ Within a row, means without a common superscript differ $(P<0.05)$

A. A: Acacia angustissima

The increase in the proportion of thighs with the addition of leaf meal could be related to the decrease in carcass weight with increasing levels of the leaf meal. According to Faria et al. (2010), for parts that are involved in locomotion, yield is increased as carcass weight is reduced, because the bones associated with movement develop early compared with other parts. The inclusion of leaf meal mostly affected the thigh and breast components, possibly due to higher nutritional requirements by the breast and thigh muscles.

At $5 \%$ inclusion, the leaf meal did not negatively affect breast muscle accretion. The significant decline in breast yield and meat to bone ratio at $10 \%$ inclusion indicates that the birds could not attain the desired breast muscle growth from the diet. This could be a result of nutritional inefficiencies associated with leaf meal presence at $10 \%$. For instance, the diet may have failed to meet the high nutritional requirements required for maximal breast meat yield (Relandeau \& Le Bellogo, 2004) owing to the effect of the fibrous nature of $A$. angustissima leaf meal on supply parameters such as VFI. Inclusion of the leaf meal may also have interfered with the availability and metabolism of lysine. Since the breast has specific lysine requirements for meat deposition (Labadan et al., 2001; Rostagno et al., 2007), any negative effect on its utilization would translate to inferior breast yield. It is also possible that at $10 \%$ inclusion, nutrients that would normally be designated to growth of late maturing tissues such as breast were used by supply organs such 
as the stomach and intestine for more important physiological supply functions (Ncube et al., 2017ab). The inclusion of the leaf meal may also have created a nutritional environment in which the breast tissue was catabolized (Noy \& Sklan, 1998; Halevy et al., 2006) to supply nutrients required for maintenance of supply organs, resulting in inferior breast meat yield from the 10\% group (Vieira \& Angel, 2012).

There were no significant differences in the chemical composition of the breast meat $(P>0.05)$ (Table 8). Physical analysis showed significantly lower lightness and higher shear force $(P<0.05)$ of breast meat from broilers fed diets with $10 \%$ leaf meal. The cooking loss and yellowness were elevated in breasts from diets with leaf meal. The physical characteristics of the meat were maintained at $5 \%$ inclusion of the leaf meal. At $10 \%$ inclusion, the decline in meat lightness value, coupled with the increase in the yellowness, is indicative of a shift from the normal broiler meat colour. The lightness value from the broilers fed $10 \%$ was outside the expected range (Petracci et al., 2004). The meat colour shift on addition of the leaf meal could be explained by the presence of pigments. Legume leaf meals contain oxycarotenoids (D'Mello et al., 1987). Since colour is one of the most important parameters affecting initial purchase decisions (Resurreccion, 2003), inclusion of the leaf meal at $10 \%$ could have a negative effect on consumer buying decisions (Wilkins et al., 2000; Qiao et al., 2001; Perez-Alvarez \& Fernandez-Lopez, 2012).

Table $\mathbf{8}$ Chemical and physical characteristics of breast meat of broilers fed graded levels of $A$. angustissima leaf meal

\begin{tabular}{|c|c|c|c|c|}
\hline Variable & Control & $5 \%$ A. A & $10 \%$ A. A & $P$ value \\
\hline \multicolumn{5}{|c|}{ Chemical parameters } \\
\hline Dry matter (\%) & $27.48 \pm 0.91$ & $27.79 \pm 1.21$ & $27.02 \pm 1.59$ & 0.2716 \\
\hline Crude protein (\%) & $25.71 \pm 1.35$ & $26.86 \pm 1.47$ & $25.66 \pm 0.87$ & 0.0699 \\
\hline Crude fat (\%) & $2.07 \pm 1.30$ & $1.12 \pm 0.69$ & $1.42 \pm 0.60$ & 0.0773 \\
\hline Ash (\%) & $1.13 \pm 0.64$ & $1.24 \pm 0.54$ & $1.26 \pm 0.59$ & 0.8824 \\
\hline \multicolumn{5}{|c|}{ Physical parameters } \\
\hline Lightness $\left(\mathrm{L}^{*}\right)$ & $53.66 \pm .062^{\mathrm{a}}$ & $50.33 \pm .062^{\mathrm{a}}$ & $49.23 \pm 1.062^{b}$ & 0.0172 \\
\hline Redness $\left(a^{*}\right)$ & $10.53 \pm 0.615$ & $11.59 \pm .615$ & $10.15 \pm 0.615$ & 0.2467 \\
\hline Yellowness $\left(b^{*}\right)$ & $12.93 \pm .868^{\mathrm{a}}$ & $18.25 \pm .868^{\mathrm{b}}$ & $19.97 \pm 0.868^{b}$ & $<0.0001$ \\
\hline Shear force $(N)$ & $14.14 \pm .088^{\mathrm{a}}$ & $14.19 \pm .088^{\mathrm{a}}$ & $14.54 \pm 0.088^{b}$ & 0.0060 \\
\hline Cooking loss (\%) & $5.95 \pm 0.411^{\mathrm{a}}$ & $6.53 \pm .411^{\mathrm{ab}}$ & $7.64 \pm 0.411^{b}$ & 0.0225 \\
\hline
\end{tabular}

${ }^{\mathrm{abc}}$ Within a row, means without a common superscript differ $(P<0.05)$

A. $\mathrm{A}=$ Acacia angustissima

Cooking loss refers to the water percentage that is lost in cooking (Al-Owaimer et al., 2014). Results from this study indicate that increasing levels of leaf meal made the broiler meat drier, and this is not a desirable effect. High cooking loss also implies the poor ability of the meat to hold water during processing and storage (Petracci \& Cavani, 2012; Abu et al., 2015). High cooking loss from the birds fed $10 \%$ is also associated with high nutrient loss during cooking (Al-Owaimer et al., 2014). As a result, the breast meat of broilers fed $10 \%$ diets also became tougher.

Figure 1 and 2 show plots of the rotated loading matrix for the principal components, a visual relationship between attributes and treatment. As shown in Figures 1 and 2, taste varied, together with overall liking. In Figure 1, taste was the most important component across determining overall liking of meat in principal component 1 , the horizontal axis. There was no established pattern for attributes along principal components 2 and 3, showing wide variations in scoring by the population of study. The correlations between taste and overall liking were $0.529,0.606$, and 0.607 for the control, $5 \%$, and $10 \%$ diets, respectively. These results show that taste was strongly related to overall liking. This implies that taste was more important for the population of study than other attributes. As such, any treatment with negative effects on broiler meat taste is likely to affect repeat purchasing decisions by consumers in the current population. The positive correlation between taste and overall liking implies that an increase in meat taste led to increased overall preference of the meat. Concurring with the current results, Horsted et al. (2011) reported a significant correlation between overall liking and scores of taste in broiler meat. 


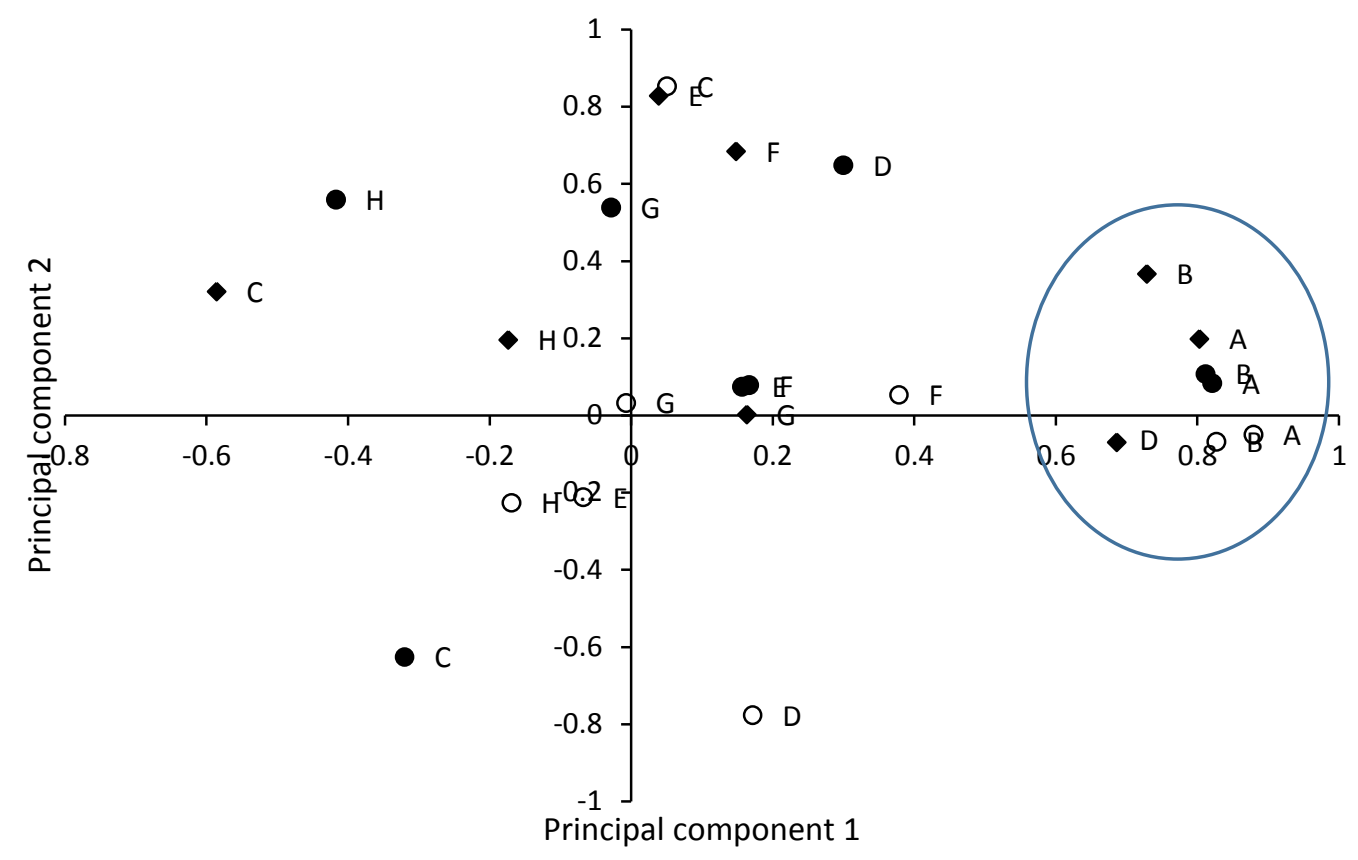

Figure 1 Component patterns (rotated) for principal components 1 and 2

Key: control diet $(\circ)$, diet with $5 \% \mathrm{~A}$. angustissima $(\bullet)$ and diet with $10 \% \mathrm{~A}$. angustissima $(\bullet) \mathrm{A}=$ Taste; $\mathrm{B}=$ Overall liking; $\mathrm{C}=$ Abnormal flavour intensity; $\mathrm{D}=$ flavour; $\mathrm{E}=$ Juiciness; $\mathrm{F}=$ Tenderness; $\mathrm{G}=$ Odour, $\mathrm{H}=\mathrm{Colour}$ )

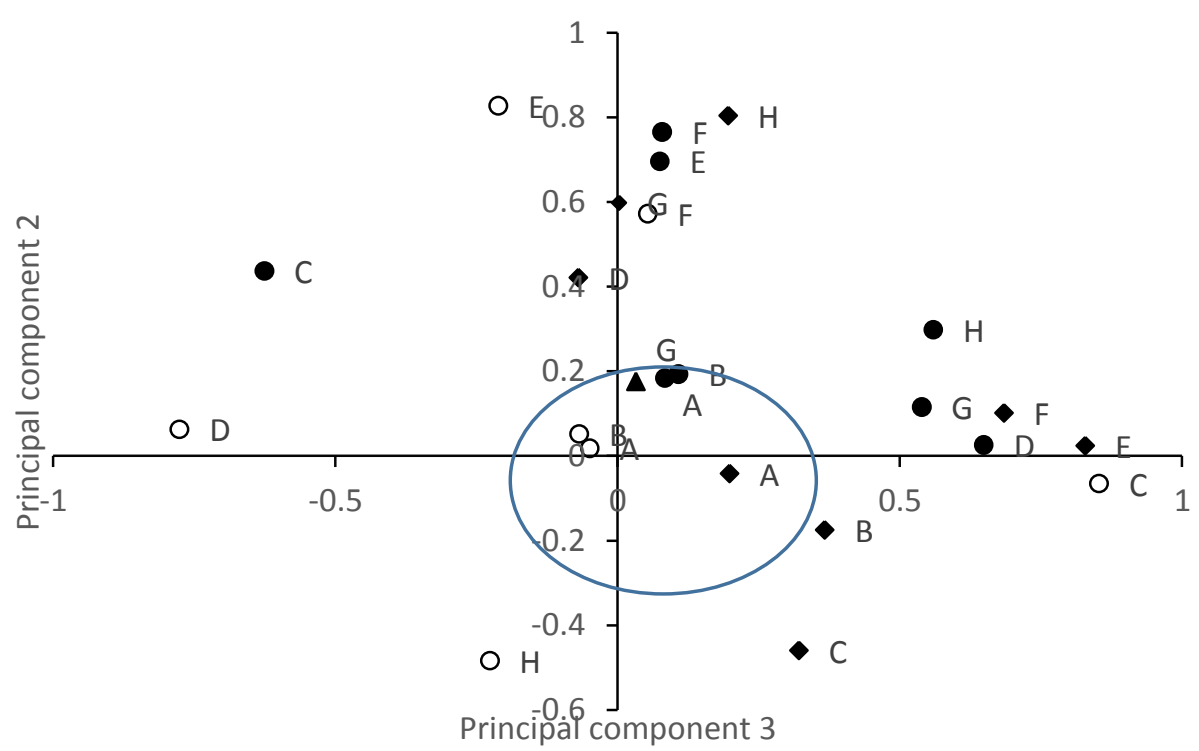

Figure 2 Component patterns (rotated) for principal components 2 and 3

Key: control diet $(\circ)$, diet with $5 \% \mathrm{~A}$. angustissima $(\bullet)$ and diet with $10 \% \mathrm{~A}$. angustissima $(\bullet) \mathrm{A}=$ Taste; $\mathrm{B}=$ Overall liking; $\mathrm{C}=$ Abnormal flavour intensity; $\mathrm{D}=$ flavour; $\mathrm{E}=$ Juiciness; $\mathrm{F}=$ Tenderness; $\mathrm{G}=$ Odour, $\mathrm{H}=$ colour

Further analysis of the organoleptic scores indicated that treatment had an effect on the degree of consumer preference in all organoleptic characteristics $(P<0.05)($ Table 9$)$. The preference for meat colour, juiciness and tenderness declined with increasing levels of leaf meal $(P<0.05)$. The intensity of the abnormal 
broiler flavour increased with increasing leaf meal content in the diet $(P<0.05)$. The significant decline in the scores for aroma, flavour and taste with increasing leaf meal content $(P<0.05)$ indicated increased preference with increasing levels of the leaf meal. Juiciness, tenderness and overall liking scores for the control and $5 \%$ diets did not differ $(P>0.05)$, but were better than those from the $10 \%$ group $(P<0.05)$.

Table 9 Average organoleptic scores for birds fed graded levels of Acacia angustissima leaf meal

\begin{tabular}{lccc}
\hline \multirow{2}{*}{ Organoleptic characteristic } & \multicolumn{3}{c}{ Average treatment scores } \\
\cline { 2 - 4 } & Control & $\mathbf{5 \%}$ Leaf meal & $\mathbf{1 0 \%}$ Leaf meal \\
\hline Colour & $1.48^{\mathrm{a}}$ & $2.18^{\mathrm{b}}$ & $3.43^{\mathrm{c}}$ \\
Aroma & $3.38^{\mathrm{a}}$ & $2.35^{\mathrm{b}}$ & $1.89^{\mathrm{c}}$ \\
Flavour & $3.78^{\mathrm{a}}$ & $2.71^{\mathrm{b}}$ & $2.02^{\mathrm{c}}$ \\
Abnormal flavour intensity & $4.18^{\mathrm{a}}$ & $3.38^{\mathrm{b}}$ & $2.32^{\mathrm{c}}$ \\
Taste & $3.19^{\mathrm{b}}$ & $2.60^{\mathrm{a}}$ & $2.38^{\mathrm{a}}$ \\
Juiciness & $2.79^{\mathrm{a}}$ & $2.93^{\mathrm{a}}$ & $3.45^{\mathrm{b}}$ \\
Tenderness & $2.50^{\mathrm{a}}$ & $2.55^{\mathrm{a}}$ & $3.19^{\mathrm{b}}$ \\
Overall liking & $2.24^{\mathrm{a}}$ & $2.42^{\mathrm{a}}$ & $2.97^{\mathrm{b}}$ \\
\hline
\end{tabular}

${ }^{\mathrm{abc}}$ Within a row, means without a common superscript differ $(P<0.05)$

The decline in the aroma, flavour and taste scores indicates a possible enhancement of those organoleptic attributes with increasing levels of the leaf meal in the diet. It was interesting that the consumers noted an increase in intensity of abnormal flavour with increasing leaf meal, but still rated flavour better as the level of leaf meal in the diet increased. The increase in the abnormal flavour seems to explain the enhanced flavour from broilers fed the leaf meal-based diets. According to Melton (1983), feeding of forages to animals can alter meat flavour as a result of changes in the fatty acid composition (Nuernberg et al., 2005). Because an increase in $A$. angustissima levels improved the taste scores, the leaf meal could play a role in improving the acceptability of broiler meat. Taste was also the most important sensory attribute influencing overall liking of meat.

The increase in the intensity of abnormal chicken flavour on inclusion of $A$. angustissima in broiler diets was expected to have a negative effect on the flavour rating of the meat. However, the opposite was true in this study, possibly implying preference towards the detected abnormal flavour. This preference might be related to the gamey taste of meat from animals fed plant-based diets. Consistent with this study, Jang et al. (2008) reported enhancement of flavour after feeding a mixture of herbal tree extracts to broilers. Aderinola et al. (2013) also reported enhanced taste, aroma and flavour of M. oleifera-fed broilers. While taste was enhanced, even at $10 \%$ inclusion of the leaf meal, it is possible that the reported increase in cooking loss resulted in inferior overall liking scores of the 10\% group. According to Michalczuk et al. (2014), high meat cooking loss has an adverse effect on sensory perception as it reduces juiciness.

\section{Conclusion}

For optimum yield of parts of economic importance, chemical, physical and organoleptic characteristics in broiler meat, up to 5\% A. Angustissima leaf meal should be included in broiler diets. At $10 \%$ inclusion, breast meat percentage declined. As dietary leaf meal addition increased, the meat grew tougher and cooking losses increased. The study concluded that up to $5 \% \mathrm{~A}$. angustissima leaf meal inclusion had no negative effects on performance yield of carcass parts and meat quality characteristics of broilers.

\section{Acknowledgements}

The authors are grateful for the financial support from DAAD and the University of Zimbabwe

\section{Authors' Contributions}

SN did the initial study design, collected all data and drafted first draft, which was reviewed by THE, EVIC and PTS. TEH and PTS also helped in the designing of the study. TEH and EVIC analysed and interpreted the data 


\section{Conflict of Interest Declaration}

There are no conflicts of interest.

\section{References}

Abu, O.A., Olaleru, I.F. \& Omojola, A.B., 2015. Carcass characteristics and meat quality of broilers fed cassava peel and leaf meal as replacements for maize and soyabean meal. J. Agric. Vet. Sci. 8(3), 41-46.

Aderinola, O.A., Rafiu, T.A., Akinwumi, A.O., Alabi, T.A. \& Adeagbo, O.A., 2013. Utilization of Moringa oleifera leaf as supplement in broiler diet. Int. J. Food, Agric. Vet. Sci. 3(3), 94-102.

Al-Owaimer, A.N., Alyemni, A.H., Suliman, G.M. \& Abudabos, A.M., 2014. Effect of different probiotics on breast quality characteristics of broilers under Salmonella enterica subsp. typhimurium challenge. Italian J. Anim. Sci. 13(3), 450-454

AMSA, 2012. Meat colour measurement guidelines. American Meat Science Association, Illinois, USA.

AOAC, 1990. Official Methods of Analysis of the Association of Official Analytical Chemists. 15th edition. Washington DC, USA.

Bonsu, F.R.K., Kagya-Agyemang, J.K., Kwenin, W.K.J. \& Zanu, H.K., 2012. Medicinal response of broiler chickens to diets containing Neem (Azadirachta indica) leaf meal, hematology and meat sensory analysis. World Appl. Sci. J. 19 (6), 800-805.

D'Mello, J.P.E, Acamovic, T. \& Walker, A.G., 1987. Evaluation of Leucaena leaf meal for broiler growth and pigmentation.Trop. Agri. (Trinidad). 64, 33-35.

Dzowela, B.H., Hove, L., Maasdorp, B. \& Mafongoya, P.L., 1997. Recent work on the establishment, production and utilization of multipurpose trees as a feed resource in Zimbabwe. Anim. Feed Sci. Tech. 69(1-3), 1-15.

Faria, P.B., Bresson, M.C., de. Souza, X.R., Rossato, L.V., Botega, L.M.G. \& da. Gama, L.T., 2010. Carcass and parts yield of broilers reared under a semi-extensive system. Braz. J. Poult. Sci. 12(3), 153-159.

Ferket, P.R. \& Gernat, A.G., 2006. Factors that affect feed intake of meat birds: A review. Int. J. Poult. Sci. 5, $905-911$.

Frutos, P., Hervas, G., Giraldoz, F.J. \& Mantecon, A.R., 2004. Review: Tannins and ruminant nutrition. Spanish J. Agri. Res. 2(2), 191-202.

Grunert, K.G., Bredahl, L. \& Brunsø, K., 2004. Consumer perception of meat quality and implications for product development in the meat sector - A review. Meat Sci. 66, 259-272.

Halevy, O., Yahav, S. \& Rozenboim, I., 2006. Enhancement of meat production by environmental manipulations in embryo and young broilers. World Poult. Sci. J. 62, 485-497.

Horsted, K., Allesem-Holm, B.H., Hemansen, J.E. \& Kongsted, A.G. 2011. Sensory profiles of breast meat from broilers reared in an organic niche production systems and conventional standard broilers. J. Sci. Food Agric. 92, 258-265

Hove, L., Chakoma, C. \& Nyathi, P., 1999. The potential of tree legume leaves as supplements in diets for ruminants in Zimbabwe. In: Strategies for dry season feeding of animals in central and southern Africa. FAO Corporate Repository.

Jang, A., Liu, X. D., Shin, M. H., Lee, S. K., Lee, J. H. \& Jo, C., 2008. Ant oxidative potential of raw breast meat from broiler chicks fed a dietary medicinal herb extract mixture. Poult. Sci. 87, 2380-2389.

Kaiser, H. F., 1960. The application of electronic computers to factor analysis, Educ. Psychol. Meas. 20, 141-151.

Karaoğlu, M., Aksu, M. İ., Esenbuğa, N., Kaya, A. \& Macit, M., 2014. Carcass and commercial cuts yield in broilers of different ages fed diets supplemented with probiotics. Afr. J. Food Sci. Technol. 5(2), 46-52.

Labadan, M.C., Hsu, K.N. \& Austic, R.E., 2001. Lysine and arginine requirements of broiler chickens at two to three week intervals to eight weeks of age. Poult. Sci. 80, 599-606.

Leeson, S. 2002. What motivates chickens to eat specific nutrients? World Poult. 18(3): 15-16.

Marcu, A., Vacaru-Opris, I., Dumitrescu, G., Marcu, A., Ciachina, L. P., Nicula, M., Dronca, D. \& Kelciov, B., 2013. Effect of diets with different energy and protein levels on breast muscle characteristics of broiler chickens. Anim. Sci. Biotechnol. 46(1), 333-340.

Mbajiorgu, C. A., Ng`ambi, J. W. \& Norris, D. D., 2011. Voluntary feed intake and nutrient composition in chickens. Asian J. Anim. Vet. Adv. 6, 20-28.

McDonald, P., Edwards, R. A., Greenhalgh, J. F. D., Morgan, C. A., Sinclair, L. A. \& Wilkinson, R. G., 2010. Animal Nutrition. 7th edition. Prentice Hall, UK.

Medugu, C.I., Kwari, I. D., Igwebuike, J., Nkama, I., Mohammed, I. D. \& Hamaker, B., 2010. Carcass and blood components of broiler chickens fed sorghum or millet as replacement for maize in the semi-arid zone of Nigeria. Agric. J. North America, 1(3), 326-329.

Melton, S. L., 1983. Effect of forage feeding on beef flavour. Food Technol. 37, 239-248.

Michalczuk, M., Łukasiewicz, M., Zdanowska-Sąsiadek, Ż. \& Niemiec. J., 2014. Comparison of selected quality attributes of chicken meat as affected by rearing systems. Pol. J. Food Nutr. Sci. 64 (2), 121-126.

Muktar, A., Adzitey, F., Teye, G. A., Alhassan, M. \& Dei. H. K., 2015. Effects of Albizia julibrissin leaf meal-based diet on carcass and sensory characteristics of broiler chickens. Global J. Anim. Sci. Res. 3(2), 388-392.

Ncube, S., Hamudikuwanda, H. \& Saidi, P. T., 2012a. The potential of Acacia angustissima leaf meal as a supplementary feed source in broiler finisher diets. Int. J. Poult. Sci. 11 (1), 55-60.

Ncube, S., Hamudikuwanda, H. \& Saidi, P. T., 2012b. Voluntary feed intake and growth of broilers on Acacia angustissima leaf meal based starter and finisher diets. Livest. Res. Rural Dev. 24(128). 
Ncube, S., Hamudikuwanda, H. \& Saidi, P. T., 2012c. Carcass yield and characteristics in broilers fed Acacia angustissima leaf meal-based diets. J. Zim. Studies: Sci, Technol. Health. 1 (1), 72-78.

Ncube, S., Saidi, P. T. \& Halimani, T. E., 2015. Effect of stage of growth and processing methods on the nutritional content of Acacia angustissima leaf meal harvested for broiler feeding. Livest. Res. Rural Dev. 27(89).

Ncube, S., Halimani, T. E. Mwale, M \& Saidi, P. T. 2017a. Effect of Acacia angustissima Leaf Meal on the Physiology of Broiler Intestines. J. Agri. Sci. 9(2), 53-61.

Ncube, S., Halimani, T. E., Tivapasi, M. T., Dhliwayo, S., Chikosi, E. V-I. \& Saidi, P. T., 2017b. Stomach adaptations of broilers fed Acacia angustissima leaf meal based diets. Online J. Anim. Feed Res. 7(3), 58-64.

Nuernberg, K., Wood, J. D., Scollan, N. D., Richardson, R. I., Nute, G. R. \& Nuernberg, G., 2005. Effect of a grass-based and a concentrate feeding system on meat quality characteristics and fatty acid composition of longissimus muscle in different cattle breeds. Livest. Prod. Sci. 94, 137-147.

Noy, Y. \& Sklan, D., 1998. Yolk utilization in the newly hatched poultry, Br. Poult. Sci. 39, 446-451.

Odenyo, A. A., Osuji, P. O., Reed, J. D., Smith, A. H., Mackie, R. I., McSweeney, C. S. \& Hanson, J., 2003. Acacia angustissima: Its antinutrients, constituents, toxicity and possible mechanism to alleviate the toxicity-A short review, Agrofor. Syst., 59, 141-147.

Onunkwo, D. N \& George, O. S., 2015. Effects of Moringa oleifera leaf meal on the growth performance and carcass characteristics of broiler birds. J. Agric. Vet. Sci. 8(3), 63-66.

Onyimonyi, A.E., Chukwuma, P.C. \& Igbokwe C., 2011. Growth and hypocholesterolemic properties of dry garlic powder (Allium sativum) on broilers. African J. Biotech. 11(11), 2666-2671.

Parsaie, S., Shariatmadari, F., Zamiri, M.J. \& Khajeh, K., 2006. Evaluation of Starch, Soluble and Insoluble Non-starch Polysaccharides and Metabolisable Energy of 15 Cultivars of Iranian Wheat. J. Agric. and Social Sci. 2(4), 260263

Perez-Alvarez, J. A. \& Fernandez-Lopez, J., 2012. Chemical and biochemical aspects of colour in muscle foods. In: Handbook of meat, poultry and seafood quality. 2nd edition. Blackwell, lowa, USA.

Petracci, M., Betti, M., Bianchi, M. \& Cavani, C. 2004. Colour variation and characterization of broiler breast meat during processing in Italy. Poult Sci. 83, 2086-2092.

Petracci, M. \& Cavani, C., 2012. Muscle growth and poultry meat quality issues. Nutr. 4(1), 1-2.

Preece, D. \& Brook, R., 1999. Acacia angustissima-a promising species for agroforestry? In: FACT sheet 98-01, January 1999. A quick guide to multipurpose trees from around the world, FACT Net, Winrock International, Arkansas.

Porter, L. J., Hrstich, L. N. \& Chan, B. G., 1986. The conversion of procyanidins and prodelphinidins to cyanidin and delphinidin. Phytochemistry, 25, 223-230.

Qiao, M., Fletcher, D. L., Smith, D. P. \& Northcutt, J. K., 2001. The effect of broiler breast meat colour on pH, moisture, water holding capacity and emulsification capacity, Poult. Sci. 80, 676-680.

Reed, J. D., Girmal, G. M., Robinson, C. J., Honson, J., Odenyo, A. \& Treichel, P. M., 2001. Acetyl-diaminobutanoic acid, a potential lathyrogenic amino acid in leaves of Acacia angustissima. J. Sci. Food Agric. 81(15), 1481-1486.

Relandeau, C. \& Le Bellogo, L., 2004. Amino acid nutrition of broiler chicken update on lysine, threonine and other amino acids. Ajinomoto Bulleting, 27, 1-36.

Resurreccion, A.V.A., 2003. Sensory aspects of consumer choices for meat and meat products. Meat Sci. 66, 11-20.

Richards, M. P. \& Proszkowiec-Weglarz, M., 2007. Mechanisms regulating feed intake, energy expenditure and body weight in poultry. Poult. Sci. 86. 1478-1490.

Rosa, P. S., Foria, F. D. E., Dahlke, F., Vieira, B. S., Macari, M., \& Furlan, R. L., 2007. Effect of energy intake on performance and carcass composition of broiler chickens from 2 different genetic groups. Brazilian J. Poult. Sci. 9(2), 117-122.

Rostagno, H., Paez, L. \& Albino, L., 2007. Nutrients requirements of broilers for optimum growth and lean mass, 16th European Symposium on Poultry Nutrition. pp 91-98.

Sahraei, M., 2012. Feed restriction in broiler chickens production: A review. Global Veterinaria, 8 (5), 449-458.

Sakamura, N. K., 2004. Modelling energy utilization in broiler breeders, laying hens and broilers. Brazilian J. Poult. Sci. $6(1), 1-11$.

Scheuermann, G. N., Bilgili, S. F., Hess, J. B. \& Mulvaney, D. R., 2003. Breast muscle development in commercial broiler chickens. Poult. Sci. 82, 1648-1658.

Scott, T. A., 2005. Variation in feed intake of broiler chickens. Recent Advances in Animal Nutrition in Australia. 15,237242.

Shim, M. Y., Tahir, M., Karnuah, A. B., Miller, M., Pringle, T. G., Aggrey, S. E. \& Pesti, G. M., 2012. Strain and sex effects on growth performance and carcass traits of contemporary commercial broiler crosses. Poult. Sci. 91, 2942-2948.

Statistical Analysis System (SAS), 2000. User's Guide. Statistics, SAS Institute Inc. Cary, North Cariolina, USA.

Onyimonyi, A. E., Adeyemi, O. \& Okeke, G.C., 2009. Perfomance and economic characteristics of broilers fed varying levels of Neem leaf meal (Azadirachta Indica). Int. J. Poult. Sci. 8(3), 256-259.

Onunkwo, D. N. \& George, O. S., 2015. Effects of Moringa oleifera leaf meal on the growth performance and carcass characteristics of broiler birds. J. Agric. Vet. Sci. 8(3) 63-66.

Taylor-Pickard, J. A. \& Spring, P., 2008. Gut efficiency; the key ingredient in pig and poultry production. Elevating animal performance and health. Wageningen Academic Publishers. The Netherlands.

Tinôco, A. L. A., Toledo, T. O., Tinôco, I. F. F., Gates, R. S. \& Xin, H., 2003. A challenge for industry to transform chicken skin into leather to benefit food safety and human health. Conference proceedings of the ASAE Annual International Meeting, Riviera Hotel and Convention Center Las Vegas, Nevada, USA 27- 30 July, Agricultural and Bio-systems Engineering. 
Uchegbu, M. C., Irechukwu, N. M., Omede, A. A., Nwaodu, C. H., Anyanwu, G. A., Okoli, I. C. \& Udedibie, A. B. I., 2009. Comparative evaluation of three commercial feeds on the performance of broilers. Report and Opinion, 1(4), 8489.

Vieira, S. L \& Angel, C. R., 2012. Optimizing broiler performance using different amino acid density diets. What are the limits, Appl. Poult. Res. 21(1), 149-155.

Wilkins, L. J., Brown, S. N., Phillips, A. J. \& Warriss, P. D. 2000. Variation in the colour of broiler breast fillets in the U.K. Br. Poult. Sci. 41, 308-312.

Yam, K. L. \& Papadakis, S., 2004. A simple digital imaging method for measuring and analyzing colour of food surfaces, J. Food Eng. 61: 137-142.

Zijlstra, R.T., Nyachoti C. M., Scott, T. A., Whittington D. L., Gonjou H.W. \&. Patience, J. F., 1999. Factors that influence voluntary feed intake. Annual Research Report. Prairie Swine Centre Inc. 